\title{
Rainfall Uncertainty and Drought Proofing Strategies by farmers in Southern India
}

\author{
K. Palanisami a*, D. Suresh Kumar b, T. Mohanasundari c \\ a Emeritus Scientist, International Water Management Institute (IWMI). New Delhi \\ b Professor (Agricultural Economics), Tamil Nadu Agricultural University, Coimbatore \\ c Assistant Professor, Department of Agricultural Economics, PGP College of Agricultural Sciences, Namakkal, Tamil Nadu
}

*Corresponding Author palanisami.iwmi@gmail.com (K. Palanisami)

Received : 24 03 2019 Accepted: 03 05 2019

\begin{abstract}
Droughts are a common occurrence in semi arid areas and their frequency and intensity is expected to increase further with increasing variability in rainfall distribution. Based on a study of 120 farmers from 4 districts in Karnataka and Tamil $\mathrm{Nadu}$, this paper identified the range of measures farmers adopt in response to droughts. Despite significant negative externalities, farmers assign higher priority to drilling new wells rather than investing in water conservation structures or demand management strategies. Among the different strategies followed, adoption of drip irrigation and purchase of tanker water for providing life saving irrigation to perennial crops yield the highest financial return. Expansion of micro irrigation and reuse of municipal waste water are suggested as drought mitigation strategies.
\end{abstract}

Keywords: Rainfall variation, drought proofing, well investment, cost of water, micro irrigation, waste water reuse

\section{Introduction}

Drought has been a common phenomenon and its occurrence is not a shocking one. For a period 1871 to 2002, India experienced 22 droughts, of which 5 were severe. Drought is a normal feature of climate, and it will keep occurring at intervals. Meteorologically, $\pm 19 \%$ deviation from the long-term mean is considered as normal whereas deficiency in the range of $20-59 \%$ is considered as moderate drought and more than $60 \%$ is severe drought (Samra, 2004).

To manage droughts, the Central and State governments have implemented several measures like construction of larger reservoirs, water harvesting structures, designing institutional arrangements for drought monitoring (like Indian Meteorological Department), early warning, relief measures and so on. There are essentially two major drought proofing measures on a long-term basis:[1] harness water through further spread of irrigation, groundwater and watershed development; and [2] evolve and spread drought resistant and short duration high yielding varieties (Ahluwalia 1991). In recent years, augmenting groundwater through artificial recharge and watershed development programs has also assumed importance (Palanisami and Kumar 2006).

Keeping recurring droughts one side and farmers' responses on the other, this paper aims to examine drought proofing measures adopted by farmers in response to recent drought of 2015 16 and the effectiveness of these measures. Such an exercise can help the planning process for tackling future droughts in different parts of the country.

\section{Data and Methods}

Our study relied on field survey conducted during May August 2017 in two districts (Coimbatore and Tirupur) of Tamil Nadu and two districts (Tumkur and Bijapur) of Karnataka. The data pertained to the agricultural year 2015 16 and the survey covered 30 well irrigated farmers in each district. Water availability at farm was calculated by collecting water in bucket with timer and the same was calculated for one hour which again multiplied by number of hours water was pumped in a day. Some of the details available from recent studies in selected locations in Karnataka were also utilized (Palanisami and Doraisamy 2016; Water Technology Centre 2015; Palanisami et al. 2015).

\section{Rainfall analysis by Gamma distribution}

Variation in rainfall was the key factor contributing for the droughts and farmers interventions in managing the crop production. The annual average (normal) rainfall of the Coimbatore, Tirupur, Tumkur and Bijapur districts are 746 , 700,578 and $744 \mathrm{~mm}$ respectively. The coefficient of variation in rainfall was also high among the districts indicating high variability (risk) in getting the required rains during the crop seasons. In order to get an idea about the 
probability of getting the normal annual rainfall, the
probability distribution of annual rainfall was analysed using the gamma distribution:

$$
f(x)=\frac{\lambda^{k} x^{k-1} e^{-\lambda x}}{\Gamma(k)}, \lambda, k>0
$$

where $k$ and $\lambda$ are the parameters of the distribution that are estimated from the observed rainfall data from 1970 71 to 2015 16. The mean rainfall and its standard deviation are estimated by the formula

$$
\begin{aligned}
& \text { mean }=\frac{k}{\lambda} \\
& \text { Standard Deviation }=\sqrt{\frac{k}{\lambda^{2}}}
\end{aligned}
$$

The quantity of rainfall, say $x_{\alpha}$ for which $\operatorname{Pr}\left\{\right.$ Rainfall $\left.\geq x_{\alpha}\right\}=\alpha$ is obtained from the equation

$$
\int_{0}^{x_{\alpha}} f(x) d x=1-\alpha
$$

The values of $x_{\alpha}$ for various values of $\alpha$ are obtained using the MATLAB. The results indicated that the probability of getting the mean annual rainfall will be only $30 \%$ thus confirming that it is unlikely that the region will be enjoying the normal annual rains every year (Table 1). The variability in rainfall is one of the main reasons for abandonment of the rainfed agriculture by the farmers which ultimately resulted in the intensification garden land agriculture where wells are the primary source of irrigation. Also over years, farmers have resorted to various drought proofing measures in order to sustain their livelihoods. Hence analysis of farmers response to droughts is considered important.

Table 1 Expected quantity of rainfall $(\mathrm{mm})$ for a $30 \%$ probability of exceedance

\begin{tabular}{|c|c|}
\hline Districts & Rainfall $(\mathrm{mm})$ \\
\hline Tirupur & 698 \\
\hline Tumkur & 742 \\
\hline Bijapur & 570 \\
\hline Coimbatore & 742 \\
\hline
\end{tabular}

\section{Drought Proofing: Farmers response}

\subsection{Drought proofing measures adopted at farm level}

Out of the 120 farmers surveyed, $67 \%$ reported that they invested in drilling additional bore wells followed by adoption of drip irrigation to conserve water; $20 \%$ followed the traditional flood irrigation method but reducing the quantum of water they normally used to irrigate; about $10 \%$ farmers fallowed the fields as the wells dried up; and rest of the farmers adopted organic farming along with drip and mulching. Some farmers were forced to cut down 15 to $20 \%$ of the existing (old) coconut trees in order to adjust water use among the productive trees. Regarding the cropping pattern, of the total sample, 60\% cultivate perennial and annual crops (such as arecanut, coconut, grapes, sugarcane, banana etc.) while the rest grow mostly vegetables, onion and maize.

\subsubsection{Supply management}

Majority of the farmers expressed that their water level dropped significantly resulting in less number of pumping hours. From the normal pumping of 7 hours/day, it dropped to 2 hours/day and then reduced further to 1 hour/day.

Most of the farmers in our sample invested in additional bore wells with depths ranging from 700 to 1000 feet. Additional well drilling is the measure farmers always do to manage the water scarcity. The rate of well failure ranged between 70 and $90 \%$. Even then, farmers felt that some additional supplies will be useful to save the standing crops. As a consequence, the market for well drilling machines increased significantly. The annualized cost of well investment ranged from Rs.18,500 to Rs.52,500 per farm (Table 2).

Average area irrigated during the drought year was about one-third of the farm area. Even with drip, only marginal increase in area irrigated was observed and this might be due to water scarcity where farmers experienced difficulties in allocating water among the standing perennial crops such as coconut, arecanut, sugarcane and banana. Farmers who used to grow only seasonal crops like vegetables had reduced the area to almost one fourth of the farm area. Cost of irrigation water ranged from Rs.2.1 to Rs.9.2 $/ \mathrm{m}^{3}$ under minimum well water pumping situation compared to Rs. 1.6 to Rs. $6.2 / \mathrm{m}^{3}$ under normal or maximum well pumping situation.

The water availability varies from bore well to bore well depending on the volume of water delivered during pumping with an average capacity of 7.5 to $10 \mathrm{HP}$ submersible motors. Among the sample farmers with in different pumping categories (like 1 inch to 2.5 inches delivery pipes), the average water supply worked out to 6,010 litres per hour.

Farmers in Coimbatore and Tirupur districts made attempts to buy water from urban areas through tankers. The cost of water from tankers ranged between Rs.1,500 and Rs.2,000 for 12,000 litres (Rs.125 to Rs. $150 / \mathrm{m}^{3}$ ). It required about 4 trips to provide one irrigation for one acre of coconut trees. 


\begin{tabular}{|c|c|c|c|c|}
\hline Particulars & Tumkur & Bijapur & Coimbatore & Tirupur \\
\hline Rainfall during 2015 16(mm/year) & 382.0 & 377.0 & 257.6 & 254.3 \\
\hline Average farm size (acres) & 4.2 & 4.6 & 5.6 & 6.3 \\
\hline Maximum depth of existing well (feet) & 690 & 570 & 710 & 650 \\
\hline No. of new wells drilled/farm during the year & 2 & 1 & 2 & 2 \\
\hline Average depth of new wells (feet) & 800 & 750 & 1000 & 1000 \\
\hline Well failure rate (\%) & 70 & 65 & 90 & 90 \\
\hline Capital cost per well (Rs) & 65,000 & 60,000 & 80,000 & 85,000 \\
\hline Annualized cost (AC) of new well (Rs/year) & 40127 & 18520 & 49387 & 52474 \\
\hline Minimum water pumped ( $\mathrm{m}^{3} /$ year $)$ & 6374 & 8660 & 5980 & 5650 \\
\hline Maximum water pumped ( $\mathrm{m}^{3} /$ year $)$ & 9486 & 11475 & 8750 & 8270 \\
\hline Average water pumped ( $\mathrm{m}^{3} /$ year) & 7930 & 10067.5 & 7365 & 6960 \\
\hline Average area covered with flood irrigation (acres) & 1.4 & 1.8 & 1.3 & 1.2 \\
\hline Average area covered with drip irrigation (acres) & 2.2 & 2.8 & 2 & 1.9 \\
\hline $\begin{array}{l}\text { Cost of water }\left(\text { Rs. } / \mathrm{m}^{3}\right) \text { with minimum water } \\
\text { pumped }\end{array}$ & 6.30 & 2.14 & 8.26 & 9.29 \\
\hline $\begin{array}{l}\text { Cost of water }\left(\mathrm{Rs} . / \mathrm{m}^{3}\right) \text { with maximum water } \\
\text { pumped }\end{array}$ & 4.23 & 1.61 & 5.64 & 6.35 \\
\hline
\end{tabular}

Source: Field survey.

\subsubsection{Demand management}

Demand management measures are done in all the possible ways to manage the drought situation. About $80 \%$ of the farmers used drip systems and the capital cost of drip system ranged from Rs.22,000 to Rs.40,000 per acre depending on the crop and inter crop spacing. 65\% of the farmers have not availed any subsidies and invested in drip mainly due to acute water scarcity, 5\% have applied recently for subsidy and are waiting while the remaining 30\% have benefited from government subsidy which ranged from Rs.10,000 to Rs.15,000 per acre.

In several cases, farmers applied plastic and organic mulches to minimizing evaporation losses. As such, field observations and discussions with farmers indicated that about $2 \sim 5 \%$ water saving is possible due to these practices. Trenches were made with a length of 24 feet, width of 3 feet and a depth of 2.5 feet. The cost of mulching ranged from Rs.5,000 to Rs.7,500 per acre. Other practices adopted by farmers include organic practices like use of cow dung based manures and panchakavya spraying to avoid pest attack and diseases.

Reduction in applied water was observed in all crops studied. This was mainly due to the adoption of drip irrigation. The reduction ranged from $26 \%$ in grapes to 38 $\%$ in pomegranate and sugarcane. In the case of onion, maize and tomato, the reduction was $25 \%, 34 \%$, and $36 \%$ respectively.

Cost of water from different investment measures was worked out. The results show that the most cost effective measures were recharging bore wells and investing in percolation ponds. Demand management measures like adoption of drip irrigation has comparatively lower cost vis à vis options like tanker water purchase (Table 3).

Table 3. Cost of water under different drought proofing measures

\begin{tabular}{|c|c|}
\hline Drought proofing measures & Cost $\left(\mathrm{Rs} . / \mathrm{m}^{3}\right)$ \\
\hline Recharge bore well & 1.7 \\
\hline Percolation ponds (PP) & 2.8 \\
\hline Drip irrigation & 3.3 to 5.0 \\
\hline Additional (new) borewell & 4.5 to 6.5 \\
\hline Farm pond & 5.5 to 8.5 \\
\hline Farm trenches & 20.8 \\
\hline Water purchase from urban areas & 125 to 150 \\
\hline Waste water reuse & 1.5 to 5 \\
\hline
\end{tabular}


While investing in anew borewell promises reasonably cost effective water, it should be noted that each new well pumping water would lead to further exploitation of the aquifers. In areas where the level of groundwater Development is classified as "critical" or "over exploited", well drilling is not advised.
4.2 Comparing different drought proofing measures

Given the investment in different drought proofing measures, it is important to examine their relative merits in terms of benefits, rate of return and constraints which can help for planning the up scaling of these drought proofing measures (Table 4).

Table 4. Comparison of different drought proofing measures

\begin{tabular}{|c|c|c|}
\hline Measures & Current Performance & Constraints for Upscaling \\
\hline Farm trenches & $\begin{array}{c}\text { Adoption: Very low. Benefit: Increase in } \\
\text { yield } 3 \text { to } 5 \%\end{array}$ & $\begin{array}{c}\text { The technology was not accepted by the farmers. } \\
\text { They say it is disturbing the field plot layout } \\
\text { hampering tractor movement for inter } \\
\text { cultivation operations. }\end{array}$ \\
\hline $\begin{array}{l}\text { Field plastic } \\
\text { mulches }\end{array}$ & $\begin{array}{l}\text { Adoption: Low. Benefit: Increase in yield 5 } \\
\qquad 8 \%\end{array}$ & $\begin{array}{l}\text { Initial cost high; should be replaced in each } \\
\text { season due to poor quality of plastic }\end{array}$ \\
\hline Drip irrigation & $\begin{array}{l}\text { Adoption: Moderate. Benefit: Yield increase } \\
\qquad 12 \sim 15 \%\end{array}$ & $\begin{array}{l}\text { Initial cost high; poor knowledge on } \\
\text { maintenance of the system }\end{array}$ \\
\hline $\begin{array}{l}\text { Surface water } \\
\text { harvesting } \\
\text { structures - farm } \\
\text { ponds }\end{array}$ & $\begin{array}{l}\text { Adoption: Moderate. Benefit: Improvement } \\
\text { in water table depth by } 3 \sim 4 \text { feet; } 1 \sim 2 \\
\text { supplemental irrigation provided for } 1 \sim 2 \\
\text { acres. }\end{array}$ & $\begin{array}{l}\text { Initial investment is high. Not direct use during } \\
\text { droughts due to no rains.Silting is the major } \\
\text { problem due to ploughing fields in each season. }\end{array}$ \\
\hline Percolation ponds & $\begin{array}{l}\text { Adoption:By group of farmers/community. } \\
\text { Benefit: Helps recharge groundwater by } 3 \sim \\
4 \text { feet in wells located in a } 0.5 \mathrm{~km} \text { radius }\end{array}$ & $\begin{array}{l}\text { No direct use during drought due to no rains. } \\
\text { Silting is the major problem. More evaporation } \\
\text { losses. }\end{array}$ \\
\hline $\begin{array}{l}\text { Borewell recharge } \\
\text { pits }\end{array}$ & $\begin{array}{l}\text { Adoption: Low to moderate. Benefit: Water } \\
\text { table increased } 2 \sim 4 \text { feet post monsoon } \\
\text { season; average area increase } 1 \text { to } 1.5 \text { acres } \\
\text { with ID crops }\end{array}$ & $\begin{array}{l}\text { Initial investment high; Location of the borewells } \\
\text { and pits different }\end{array}$ \\
\hline New bore well & $\begin{array}{l}\text { Adoption: More extensively done. Benefit: } \\
\text { Can cover } 1 \sim 2 \text { acres }\end{array}$ & $\begin{array}{l}\text { Investment high and well failure is also very } \\
\text { high }\end{array}$ \\
\hline $\begin{array}{l}\text { Water purchase } \\
\text { from tankers }\end{array}$ & $\begin{array}{l}\text { Adoption: Practiced in coconut farms due } \\
\text { to failure of existing wells. Benefit: } 2 \sim 3 \text { life } \\
\text { saving irrigation to existing trees }\end{array}$ & $\begin{array}{l}\text { Water costly; even then, water not available in } \\
\text { peri urban and urban areas for transport } \\
\text { through tankers }\end{array}$ \\
\hline
\end{tabular}

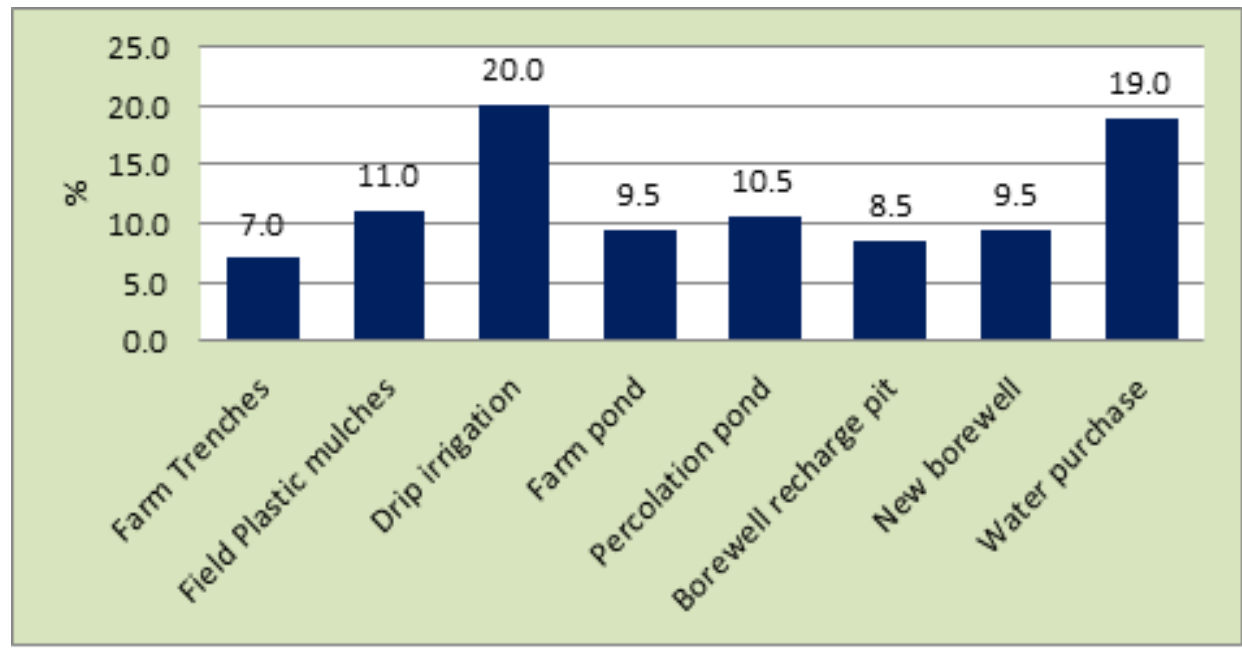

Fig 1. Comparison of rate of returns across drought proofing measures 


\section{Conclusion and Recommendations}

The probability of getting the mean annual rainfall will be only 30\% thus indicating the uncertainties in getting adequate rains every year. Hence farmers resorted to several supply augmentation measures. Most of these supply side measures (percolation ponds, farm ponds, recharge wells etc.) are inter linked and have impact during post rainy seasons. However, during droughts, vast majority of farmers' investments are made for drilling new boreholes for instant supplies. The cost of well drilling works out to be Rs.180 crores in Coimbatore district and Rs. 100 crores in Tirupur districts thus showing capital formation in agriculture is increasing through investments in borewells. This investment behaviour indicates that farmers always and in all ways make this every year. However, given the free farm power regime and tendency for over pumping, this results in negative externalities in terms of high well failure rate (90\%) and increasing cost of groundwater which will be prohibitive for agriculture production.

One area of interest will be how to use the treated domestic waste water directly for irrigation or through recharging groundwater aquifers. Given the quantum of domestic waste water generated in urban areas is as high as 67 million $\mathrm{m} 3 \mathrm{(Mm} 3$ ) in Coimbatore and $39 \mathrm{Mm} 3$ in Tirupur districts, it is possible to focus future investments in waste water treatment processes. ITP studies on the prevalence of waste water irrigation in Gujarat (Palrechaet al. 2012), Maharashtra (Palrechaet al. 2016), Karnataka (Gupta et al. 2016) and Tamil Nadu (Leaf Society 2016) found that more than 50,000 hectares are already being irrigated by farmers using untreated municipal waste water . Regarding demand management measures, use of drip irrigation is common but a major challenge of inadequate water supplies from bore wells remains. As a result, sub optimal level of irrigation water application was observed. Overall, most of the farmers growing perennial crops indicated that they will reduce the area by 20 to $30 \%$ by cutting the old trees and will start diversifying their farming activities.

Given the scope for expanding micro irrigation, continuing public support for the wider adoption and promotion of micro irrigation technologies is warranted. Financial institutions may be geared up to offer special loans for the installation of drip and sprinkler irrigation. Also special purpose vehicles like GGRC models can be introduced at state level for effective spread of MI (Palanisami and Suresh Kumar, 2017).

\section{Acknowledgement}

Thanks for the financial support provided by IWMI Tata program (ITP) of the International Water Management Institute (IWMI) and for the excellent comments of Dr Tushaar Shah and Shilp Verma of the IWMI, Anand office for preparing the ITP highlights.

\section{References}

[1] D. Ahluwalia, Drought proofing in the Indian foodgrains economy, Indian Journal of Agricultural Economics, 46 (1991) 111 120.

[2] M. Gupta, V. Ravindra and A. Palrecha, Water Policy Research Highlight\#04, Anand: IWMI Tata Water Policy Program, Wastewater irrigation in Karnataka: An exploration, (2016).

[3] Leaf Society, Unpublished draft report, Anand: IWMI Tata Water Policy Program, Wastewater irrigation in Tamil Nadu (2016).

[4] K. Palanisami and R. Doraisamy, ICRISAT IWMI Karnataka Project on Enhancing water use efficiency in agriculture. Hyderabad, Baseline study reports Tumkur, Bijapur districts (2015).

[5] K. Palanisami and D.S. Kumar, Impact assessment of watershed development: Methodological issues and experiences, Challenges in impact assessment of watershed development. In K. Palanisami and D. Suresh kumar (Eds.), Associated Publishing Company Ltd, (2006) New Delhi.

[6] K. Palanisami and D.S. Kumar, Draft unpublished report, Anand: IWMI Tata Water Policy Program, Drought proofing strategies by the farmers in southern India (2017).

[7] K. Palanisami, A. Raviraj, S. Thirumoorthi, S. Gurunathan, Dhanalakshmi and R. Shanthi, Ian Gale, David, Macdonad, Roger Calow, IIka New Man. Agumenting groundwater resources by artificial recharge, TNAU BGS study report, (2006), Tamil Nadu Agricultural University, Coimbatore.

[8] K. Palanisami, D.S. Kumar, R.P.S. Malik, S. Raman, G. Kar and K. Mohan, Managing water management research: Analysis of four decades of research and outreach programmes in India, Economic and Political Weekly, 26 27 (2015) 33 34.

[9] A. Palrecha, D. Kapoor and T. Maladi, Wastewater irrigation in Gujarat: An exploration, Water Policy Research Highlight \#30, Anand: IWMI Tata Water Policy Program, (2012).

[10]A. Palrecha, N. Sakhare, S. Patkar, S. Sule, S. Sebastian and M. Ramola, Wastewater irrigation in Maharashtra: An exploration, Water Policy Research Highlight \#09, Anand: IWMI Tata Water Policy Program (2016).

[11]J.S. Samra, Review and analysis of drought monitoring, declaration and management in India, Working Paper 84, International Water Management Institute, Sri Lanka (2004). 
[12] Water Technology Centre Impact evaluation of World Bank IAMWARM project, TamilNadu Agricultural University, Coimbatore (2015).

\section{About The License}

(C) 2019 The Authors. This work is licensed under a Creative Commons Attribution 4.0 International License which permits unrestricted use, provided the original author and source are credited. 